\title{
ASSESSMENT OF GROUNDWATER QUALITY FOR IRRIGATION ON THE BANK OF NOYYAL RIVER AT TIRUPPUR, TAMIL NADU, INDIA
}

\author{
A. Zahir Hussain and K.M Mohamed Sheriff \\ PG and Research Department of Chemistry, Jamal Mohamed College (Autonomous), \\ (Affiliated to Bharathidasan University), Tiruchirapalli, Tamil Nadu, India \\ Email address: azahirhussainchem@yahoo.co.in
}

Keywords: Groundwater, Physico-chemical parameters, Water Quality, Kelly's Ratio, CAI-1 and CAI-2

\begin{abstract}
Tiruppur is a textile city located on the banks of Noyyal River a tributary of the River Cauvery. Twenty groundwater samples were collected in identical locations from bore wells. The concentrations of physicochemical parameters of $\mathrm{pH}$, Electrical Conductivity (EC), Total Hardness (TH), $\mathrm{Ca}, \mathrm{Mg}, \mathrm{Na}, \mathrm{K}, \mathrm{HCO}_{3}, \mathrm{SO}_{4}, \mathrm{Cl}$ and $\mathrm{NO}_{3}$ were analyzed. The results of the concentrations were interpreted and measured with different irrigation indexes like Percent Sodium $(\% \mathrm{Na})$, Sodium Adsorption Ratio (SAR), Residual Sodium Carbonate (RSC), Permeability Index (PI), Kelly's Ratio (KR), CAI-1 and CAI-2 were analyzed.
\end{abstract}

\section{INTRODUCTION}

The water resource is certainly inexhaustible gift of nature. It is an established fact that proper maintenance, conservation and use of the water resource will definitely avoid the changes of water famine for future generations for an indefinite period. Once contamination of groundwater in aquifers occurs by means of industrial activities and urban development, it persists for hundreds of years because of very slow movement of water in them and prompts investigations on their quality [1]. The water quality assessment may give clear information about the subsurface geologic environments in which the water presents [2]. The addition of various kinds of pollutants and nutrients through the agency sewage, industrial effluents, agricultural run-off etc. into the water bodies brings about a series of changes in the physicochemical and characteristics of water, which have been the subject of several investigations [3]. However, increasing demand and withdrawal, significant changes in land use pattern and vast industrial effluent entering the hydrological cycle stresses the quality and quantity of groundwater [4].

Utilization of land varies from place to place due to rapid urbanization and industrialization, without following the strict environmental norms, causing a lot of variation of quality of groundwater within a short distance, which constrains the developmental activities drastically everywhere [5]. The present study was carried out for qualitative analysis based on physicochemical parameters of groundwater.

\section{MATERIALS AND METHODS}

\section{Study area}

Tiruppur is situated among latitude $11^{\circ} 10^{\prime} \mathrm{N}$ to $11^{\circ} 22^{\prime} \mathrm{N}$ and longitudes $77^{\circ} 21^{\prime} \mathrm{E}$ to $77^{\circ} 50^{\prime} \mathrm{E}$. Tirupur is a fast growing industrial city in Tiruppur district of Tamilnadu, also known as 'Banian City' of India. It is located on the bank of the Noyyal River, a tributary of the River Cauvery. The hosiery industry in Tiruppur provides substantial contribution to the economy in the form of income, employment and foreign exchange generation. However, the rapid growth of the industry has resulted in serious environmental problems, especially from the bleaching and dying units. The region is an agricultural area with paddy as the main crop. The river Noyyal is a seasonal river and it originates from Vellingiri Hills in the Western Ghats of Coimbatore District [6]. The study area occupies mostly charnockites, granites and complex gneisses which highly rich minerals such as 
pyroxene, mica, garnet etc. The place of study at which water samples are collected is referred to as "Stations". The groundwater samples are collected during winter season 2013. Five stations are selected. They are represented as Authupalayam (S1), Mangalam (S2), Karuvampalayam (S3), Mannarai (S4), Ponapuram (S5). The samples are collected in each station using sampling techniques. The samples were analyzed for Physico-chemical parameters using standard procedures [7].

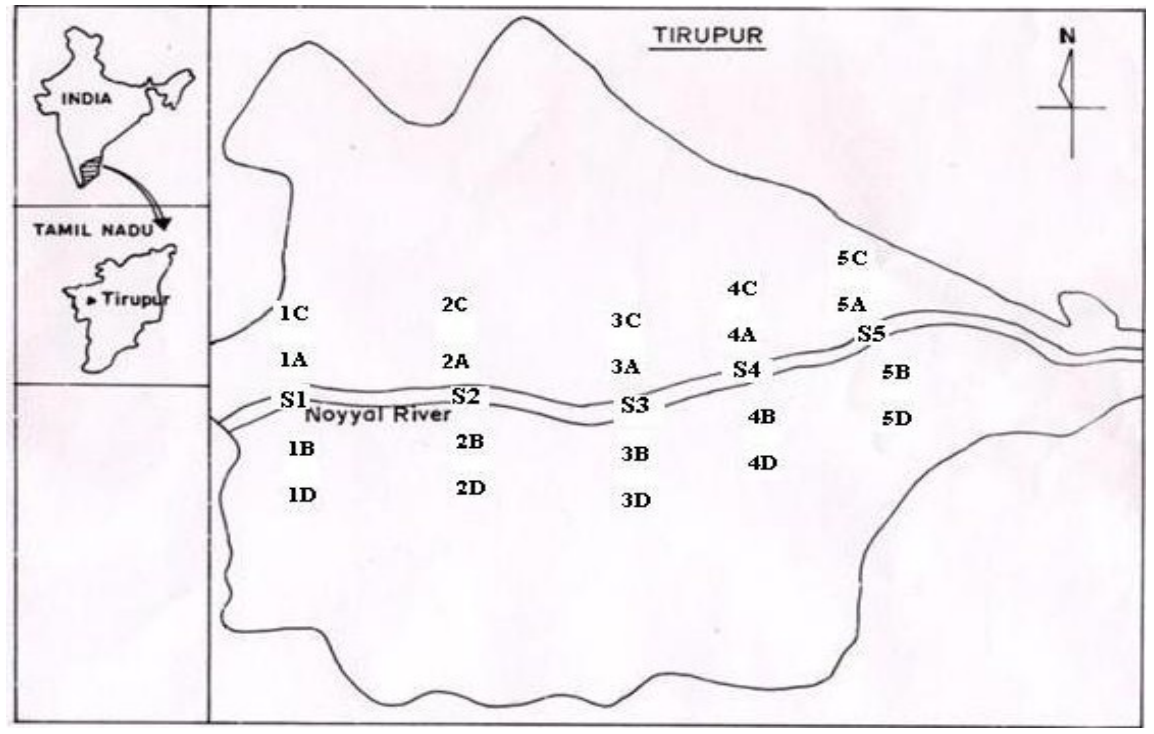

Fig. 1. Location map of study area

\section{RESULTS AND DISCUSSION}

The results of irrigational water quality parameters are tabulated in Table 6 . The results are discussed and compared with standard values of WHO [8].

\section{Residual Sodium Carbonate (RSC)}

Irrigation water containing large amounts of sodium is of special concern due to effect of sodium on the soil and poses hazards of sodium. Excess of sodium in water which produces the undesirable effects of changing soil properties and reducing soil permeability. Hence, the assessment of sodium concentration is necessary while considering the suitability for irrigation [9]

$$
\mathrm{RSC}=\mathrm{CO}_{3}^{2-}+\mathrm{HCO}_{3}^{2-}-\left(\mathrm{Ca}^{2+}+\mathrm{Mg}^{2+}\right)
$$

The RSC values are less than $1.25 \mathrm{meq} / \mathrm{L}$ in all the groundwater samples. Hence all the groundwater samples fall under safe category which can be used for irrigation purposes. Sodium concentration is important in classifying the irrigation water because sodium reacts with soil to reduce its permeability. Soils containing a large proportion of sodium with carbonate as the predominant anion are termed alkali soils; those with chloride or sulphate as the predominant anion are saline soils [10]. Hence in the present study all the groundwater samples fall under the safe category (Table 1).

Table 1. Classification of water based on RSC values.

\begin{tabular}{|c|c|c|}
\hline $\begin{array}{c}\text { RSC VALUES } \\
(\mathbf{M e q} / \mathbf{L})\end{array}$ & CLASS & STATIONS \\
\hline$<1.25$ & SAFE & All the Samples \\
\hline $1.25-2.5$ & MARGINAL & -- \\
\hline$>2.5$ & UNSUITABLE & -- \\
\hline
\end{tabular}




\section{Sodium Adsorption Ratio (SAR)}

The excessive sodium content relative to the calcium and magnesium reduces the soil permeability and thus inhibits the supply of water needed for the crops. SAR indicates the degree to which irrigation water tends to enter into cation-ex-change reactions in soil.

$$
S A R=\frac{\mathrm{Na}^{+}}{\sqrt{\mathrm{Ca}^{2+}+\mathrm{Mg}^{2+} / 100}}
$$

In the present study all the ground water samples fall within the excellent category which can be used for irrigation based on the SAR classification (Table 2). Sodium is replaced the calcium and magnesium is a hazard as it causes damage to the to the soil structure and becomes compact and impervious [11].

Table 2. Classification of water based on SAR values.

\begin{tabular}{|c|c|c|}
\hline $\begin{array}{c}\text { SAR VALUES } \\
(\mathbf{M e q} / \mathbf{L})\end{array}$ & CLASS & STATIONS \\
\hline$<10$ & EXCELLENT & All the samples \\
\hline $10-18$ & GOOD & -- \\
\hline $18-26$ & FAIR & -- \\
\hline$>26$ & POOR & -- \\
\hline
\end{tabular}

\section{Percent sodium (\% Na)}

The values of percent sodium lie in the range of 15 to $43 \%$ (Table 1). The percent sodium values fall in the range of excellent category is found at stations $1 \mathrm{~B}, 3 \mathrm{~A}, 3 \mathrm{~B}, 3 \mathrm{D}, 4 \mathrm{~A}-4 \mathrm{C}, 5 \mathrm{~A}$ and $5 \mathrm{~B}$, good category is observed at stations $1 \mathrm{~A}, 1 \mathrm{C}, 1 \mathrm{D}, 2 \mathrm{~A}-2 \mathrm{D}, 3 \mathrm{C}, 4 \mathrm{D}$ and $5 \mathrm{D}$, and permissible category is noticed at station 5C. For irrigation purpose, the percentage of sodium is important, because sodium reacts with soil to reduce permeability [12]. When the concentration of sodium is high in irrigation water, sodium ions tend to be absorbed by clay particles, displacing $\mathrm{Mg}^{2+}$ and $\mathrm{Ca}^{2+}$ ions. This exchange process of $\mathrm{Na}^{+}$in water for $\mathrm{Ca}^{2+}$ and $\mathrm{Mg}^{2+}$ in soil reduces the permeability and eventually results in soil with poor internal drainage [13]. Hence, air and water circulation is restricted during wet conditions and such soils become usually hard when dry.

$$
\% \mathrm{Na}=\frac{\mathrm{Na}^{+}+\mathrm{K}^{+}}{\mathrm{Ca}^{2+}+\mathrm{Mg}^{2+}+\mathrm{Na}^{+}+\mathrm{K}^{+}} \times 100
$$

Table 3. Classification of water based on $\% \mathrm{Na}$ values.

\begin{tabular}{|c|c|c|}
\hline \%Na VALUES & CLASS & STATIONS \\
\hline$<20$ & EXCELLENT & $1 \mathrm{~B}, 3 \mathrm{~A}, 3 \mathrm{~B}, 3 \mathrm{D}, 4 \mathrm{~A}-4 \mathrm{C}, 5 \mathrm{~A}$ and 5B \\
\hline $20-40$ & GOOD & $1 \mathrm{~A}, 1 \mathrm{C}, 1 \mathrm{D}, 2 \mathrm{~A}-2 \mathrm{D}, 3 \mathrm{C}, 4 \mathrm{D}$ and 5D \\
\hline $40-60$ & PERMISSIBLE & - \\
\hline $60-80$ & DOUBTFUL & -- \\
\hline $80-100$ & UNSUITABLE & \\
\hline
\end{tabular}




\section{Kelley's ratio (KR)}

Kelly's ratio values lie in the range of 0.13 to $0.54 \mathrm{meq} / \mathrm{L}$ (Table 6). The KR values are below the permissible limit $(>2 \mathrm{meq} / \mathrm{L})$ in all the groundwater samples . The values of Kelly's ratio is greater than two are unfit for irrigation [14]. Hence in the present study indicates that all the groundwater samples are suitable for irrigation.

$$
K R=\frac{\mathrm{Na}^{+}}{\mathrm{Ca}^{2+}+\mathrm{Mg} \mathrm{g}^{2+}}
$$

Table 4. Classification of water based on KR values.

\begin{tabular}{|c|c|c|}
\hline $\begin{array}{c}\text { KR VALUES } \\
(\mathbf{M e q} / \mathbf{L})\end{array}$ & CLASS & SAMPLES \\
\hline$<1$ & SUITABLE & All the samples \\
\hline $1-2$ & MARGINAL & -- \\
\hline$>2$ & UNSUITABLE & -- \\
\hline
\end{tabular}

\section{Permeability Index (PI)}

The soil permeability is affected by long term use of irrigation water. It is influenced by sodium, calcium, magnesium and a bicarbonate content of soil [15]. It has evolved a criterion to assess the suitability of water for irrigation based on Permeability Index (PI).

$$
\mathrm{PI}=\frac{\mathrm{Na}^{+}+\mathrm{HCO}_{3}^{-}}{\mathrm{Ca}^{2+}+\mathrm{Mg}^{2+}+\mathrm{Na}^{+}} \times 100
$$

From the obtained results, the PI values are fall under class 2 at stations 1A-4D, 5C, 5D and class 3 category is found at stations $5 \mathrm{~A}$ and $5 \mathrm{~B}$ as per Doneen's classification. This indicates that all the groundwater samples are suitable for irrigation [15].

Table 5. Classification of water based on PI values.

\begin{tabular}{|c|c|c|}
\hline $\begin{array}{c}\text { PI VALUES } \\
(\mathbf{M e q} / \mathbf{L})\end{array}$ & $\begin{array}{c}\text { LIMITING VALUES OF } \\
\text { PI }\end{array}$ & STATIONS \\
\hline$>75$ & CLASS -1 & -- \\
\hline $25-50$ & CLASS -2 & 1A-4D, 5C and 5D \\
\hline$<25$ & CLASS -3 & $5 \mathrm{~A}$ and 5B \\
\hline
\end{tabular}

\section{Chloro alkaline Indices (CAI)}

The CAI is essential to know the changes in chemical composition of groundwater during its travel in the sub-surface. The Chloro-alkaline indices CAI 1 and CAI 2 are suggested by Schoeller [16], which indicate the ion exchange between the groundwater and its host environment. The Chloroalkaline indices used in the evaluation of base Exchange are calculated using the below equations.

$$
\begin{aligned}
& \mathrm{CAI}-1=\frac{\left(\mathrm{Cl}^{-}-\left(\mathrm{Na}^{+}+\mathrm{K}^{+}\right)\right)}{\mathrm{SO}_{4}^{2-}+\mathrm{HCO}_{3}^{-}+\mathrm{CO}_{3}^{-}+\mathrm{NO}_{3}^{-}} \\
& \mathrm{CAI}-2=\frac{\left(\mathrm{Cl}^{-}-\left(\mathrm{Na}^{+}+\mathrm{K}^{+}\right)\right)}{\mathrm{Cl}^{-}}
\end{aligned}
$$


In the present study the values of CAI- 1 in the range of 0.640 to 0.983 meq/L and CAI- 2 in the range of -0.171 to $1.721 \mathrm{meq} / \mathrm{L}$ respectively. Hence most of the samples have positive values in CAI-1 and CAI-2 respectively except at station 5C. If CAI is negative, there will be an exchange between $\mathrm{Na}+\mathrm{K}$ with calcium and magnesium $(\mathrm{Ca}+\mathrm{Mg})$ in rocks. If the ratio is positive, there is no base change in CAI. The positive value indicates the absence of base exchange. The negative value of the ratio indicates base exchange between sodium and potassium in water with calcium and magnesium in the samples [17].

\section{CONCLUSION}

In the present study, the assessment of groundwater samples for irrigation has been evaluated on the basis of standard guidelines. The analysis evidently says that groundwater in the study is fit for Irrigation and other domestic purposes. Most of the groundwater samples are affected by high electrical conductivity, sodium, Potassium, TDS and Magnesium hazards as concerned with irrigation water. According to irrigation classification values the salinity of groundwater persists at majority of sites. The ground water samples leads to surface and subsurface water may interact with country rock. Hence the salinity of water and soil must be permeable with adequate drainage facilities for satisfactory crop growth.

Table 6. Shows the values of Irrigational quality of groundwater samples.

\begin{tabular}{cccccccc}
\hline STATIONS & RSC & SAR & \%NA & KR & PI & CAI 1 & CAI 2 \\
\hline 1A & 3.484 & 0.722 & 21.16 & 0.214 & 39.135 & 0.64 & 0.648 \\
1B & 5.579 & 0.701 & 18.19 & 0.177 & 31.368 & 0.919 & 0.67 \\
1C & 5.239 & 1.363 & 32.43 & 0.388 & 39.184 & 0.938 & 1.293 \\
1D & 5.141 & 1.118 & 31.2 & 0.319 & 36.484 & 0.931 & 1.287 \\
2A & 5.853 & 1.043 & 26.62 & 0.255 & 35.408 & 0.956 & 1.015 \\
2B & 5.673 & 1.138 & 27.27 & 0.281 & 37.072 & 0.953 & 0.894 \\
2C & 3.367 & 0.738 & 24.34 & 0.251 & 38.189 & 0.964 & 1.356 \\
2D & 4.141 & 0.77 & 24.29 & 0.244 & 34.469 & 0.872 & 0.719 \\
3A & 7.582 & 0.639 & 16.74 & 0.147 & 25.457 & 0.93 & 0.605 \\
3B & 7.205 & 0.587 & 15.12 & 0.136 & 25.589 & 0.947 & 0.693 \\
3C & 4.268 & 0.932 & 28.85 & 0.285 & 37.255 & 0.944 & 1.721 \\
3D & 4.369 & 0.494 & 18.09 & 0.148 & 30.118 & 0.936 & 0.851 \\
4A & -6.44 & 0.629 & 17.44 & 0.152 & 28.011 & 0.982 & 1.539 \\
4B & 6.107 & 0.764 & 20.83 & 0.187 & 30.898 & 0.95 & 1.094 \\
4C & 2.409 & 0.48 & 20.65 & 0.177 & 41.084 & 0.943 & 0.857 \\
4D & -2.97 & 0.75 & 25.95 & 0.259 & 41.539 & 0.932 & 1.338 \\
5A & 6.896 & 0.528 & 15.71 & 0.134 & 22.543 & 0.941 & 1.124 \\
5B & -7.95 & 0.717 & 20.08 & 0.169 & 24.239 & 0.918 & 0.686 \\
5C & 4.105 & 1.712 & 43.71 & 0.544 & 47.286 & 0.665 & -0.17 \\
5D & 4.648 & 0.912 & 28.22 & 0.273 & 34.988 & 0.946 & 1.711 \\
\hline
\end{tabular}

* All the above concentrations are expressed in meq/L and \% $\mathrm{Na}$ and PI in \%. 


\section{References}

[1] Jerry AN, Basic environmental technology (water supply, waste disposal and pollution control). Wiley, New York (1986).

[2] Raju NJ, Shukla UK, Ram P. Hydrogeochemistry for the assessment of groundwater quality in Varanasi: a fast-urbanizing center in Uttar Pradesh, India. Environ Monit Assess 173 (2011) 279300

[3] Mahananda M.R., Mohanty B.P. and Behera Mahananda N.R. Physico-Chemical Analysis of Surface and Ground Water of Bargarh District, Orissa, India, IJRRAS, 2 (3) (2010) 284-295.

[4] Mackey R ."Groundwater Quality" in:Thannah and Biswas, A.K(eds) Environmentally Sound Water Management, Oxford University Press (1990).

[5] Subba Rao N. Studies of water quality index in hard rock terrain of Guntur district, Andra Pradesh, India. In: National Seminar on Hydrology of Precambrian Terrains and hard rock areas, 129-134(1997).

[6] Chitradevi. S, Sridhar S.G.D, International Journal of Environmental Sciences Volume 2, No 1. (2011)

[7] APHA (American Public Health Association), Standard method for examination of water and waste water New York, 20th edition (1998).

[8] WHO, International Standards for drinking water, Geneva (2011).

[9] S. Carmelita Nishanthiny, M. Thushyanthy, T. Barathithasan and S. Saravanan. AmericanEurasian J. Agric. \& Environ. Sci., 7 (1) (2010) 100-102,

[10]. T.Suresh and N.M.Kottureshwara, Rasayan. J. Chem. Vol.2, No.1 , 221-233 (2009).

[11] Anthony Ewusi, Solomon Obiri-yeboah, Hans-jürgen Voigt, Stephen Boahen Asabere and, Crentsil Kofi Bempah. Research Journal of Environmental and Earth Sciences 5(1) (2013) 6-17.

[12] Janardhana Raju N . Hydrogoechemical parameters for assessment of groundwater quality in the upper Gunjanaeru River basin, Cuddapah District, Andhra Pradesh, South India. Eviron Geol 52:1067-1074 (2007).

[13] Saleh, A., F. Al-Ruwaih and M. Shehata. Hydrogeochemical processes operating within the main aquifers of Kuwait. J. Arid Env., 42 (1999) 195-209.

[14] Kelly VP. Alkali Soils: their formation properties and reclamations. Reinhold, New York(1951).

[15] Doneen LD. Notes on water quality in Agriculture Published as a Water Science and Engineering Paper 4001, Department of Water Science and Engineering, University of California (1964).

[16] H. Schoeller. "Geochemistry of groundwater," In: Groundwater Studies-An International Guide for Research and Practice, UNESCO, Paris, pp. 1-18 (1977).

[17] A. Jafar Ahamed, S. Ananthakrishnan , K. Loganathan and K. Mani kandan.Assessment of groundwater quality for irrigaton use in Alathur Block, perambalur district, Tamil nadu, India. Appl Water Sci, Springer 3:763-771. (2013).DOI 10.1007/s13201-013-0124-z 